\title{
Hormonal induction maturation of silver pompano Trachinotus blochii
}

\section{Induksi maturasi secara hormonal pada ikan bawal bintang Trachinotus blochii}

\author{
Wiwin Kusuma Atmaja Putra ${ }^{1 *}$, Tengku Said Raza'i ${ }^{1}$ \\ ${ }^{1}$ Aquaculture Departement, Marine Science and Fisheries Faculty, Raja Ali Haji Maritime University \\ Politeknik Streat, Senggarang, Tanjungpinang, Riau Island \\ *Corresponding author: wiwin.bdp@umrah.ac.id
}

(Received September 5, 2017; Accepted September 2, 2019)

\begin{abstract}
This study was aimed to acquire the most suitable hormone treatment to induce gonad maturation of silver pompano Trachinotus blochii. This study used a completely randomized design with four treatments and three replications, i.e $\mathrm{NaCl} 90 \%$ (control) $(0.5 \mathrm{~mL} / \mathrm{kg}$ ), hCG (20 IU/kg fish body weight), PMSG (20 IU/kg fish body weight), and PG600 (20 IU/kg fish body weight). Parameters measured were gonadosomatic index (GSI), hepatosomatic index (HSI), gonad maturity level (TKG), gonad histology, and absolute growth. The best result was PG600 treatment with $0.12 \%$ gonadosomatic index, $2.29 \%$ hepatosomatic index, TKG IV, and $85 \mathrm{~g}$ absolute growth for four weeks. This study concludes that the most suitable hormone to induce gonad maturation of silver pompano Trachinotus blochii is PG600 with $20 \mathrm{IU} / \mathrm{kg}$ body weight, which effectively affects GSI, HSI, and absolute growth of silver pompano.
\end{abstract}

Keywords: hCG, maturation, PG600, PMSG, silver pompano.

\begin{abstract}
ABSTRAK
Penelitian ini bertujuan mendapatkan hormon yang terbaik untuk menginduksi maturasi gonadikan bawal bintang. Hormon yang digunakan pada penelitian ini adalah kontrol $\mathrm{NaCl} 90 \%$ (dosis $0,5 \mathrm{~mL} / \mathrm{kg}$ ), hCG(dosis $20 \mathrm{IU} / \mathrm{kg}$ bobot tubuh ikan), PMSG (dosis 20 IU/kg bobot tubuh ikan), dan PG600 (dosis 20 IU/kg bobot tubuh ikan). Parameter yang diamati adalah indeks gonadosomatik (GSI), indeks hepatosomatik (HSI), tingkat kematangan gonad (TKG), histologi gonad, dan pertumbuhan bobot mutlak. Hasil terbaik adalah perlakuan PG600 dengan gonadosomatik indeks $(0,12 \%)$, hepatosomatik indeks $(2,29 \%)$, TKG IV, dan pertumbuhan mutlak (85 g) selama empat minggu. Kesimpulan penelitian ini adalah perlakuan hormon yang berpotensi menginduksi maturasi gonad ikan bawal bintang adalah hormon PG600 dengan dosis $20 \mathrm{IU} / \mathrm{kg}$ bobot tubuh dikarenakan adanya pengaruh nyata tehadap parameter GSI, HSI dan pertumbuhan mutlak ikan bawal bintang.
\end{abstract}

Kata kunci: ikan bawal bintang, hCG, PMSG, PG600, maturasi. 


\section{INTRODUCTION}

Silver pompano is one of superior commodities in Riau Islands Province. Problems on silver pompano culture in Riau Islands Province are low fingerling supply, insufficient fi ngerling production in culture center or fish farmers, limited spawning period (silver pompano only spawns on moon period), as well as limited matured broodstocks. These problems can be overcome by maximizing the broodstock production and improving the gonad maturation through a hormonal induction. Hormonal induction is performed as this technology minimizes the natural factors influencing the reproductive hormone performance of silver pompano to induce the gonad maturation process compared to the natural signals and nutrients. Gonad maturation is a gonad development before ovulation and spawning controlled by gonadotropin I hormone (follicle stimulating hormone (FSH)).

Gonadotropin hormones are hormones that act in the gonad maturation process of fish. Gonadotropin hormones are divided into two types, namely follicle stimulating hormone (FSH) and luteinizing hormone (LH). The gonad maturation rate can be triggered by inducing the fish with FSH and LH hormone. FSH and LH hormone can be obtained from commercial products, such as human chorionic gonadotropin (hCG), pregnant mare serum gonadotropin (PMSG), and PG600. PMSG hormone contains $\mathrm{FSH}+\mathrm{LH}$ with higher FSH concentration, while hCG also contains FSH+LH but higher LH concentration than FSH (Guzmán et al., 2011). Gonatropin hormones have functions to induce egg developmental process during the maturation process, ovulation, and spawning. Gonadotropin hormones enter theca cells and induce testosterone hormone production, then alter testosterones into estradiol hormones with the help of aromatase enzyme. Estradiols will induce liver to produce vitelogenins (egg yolk candidate), which are
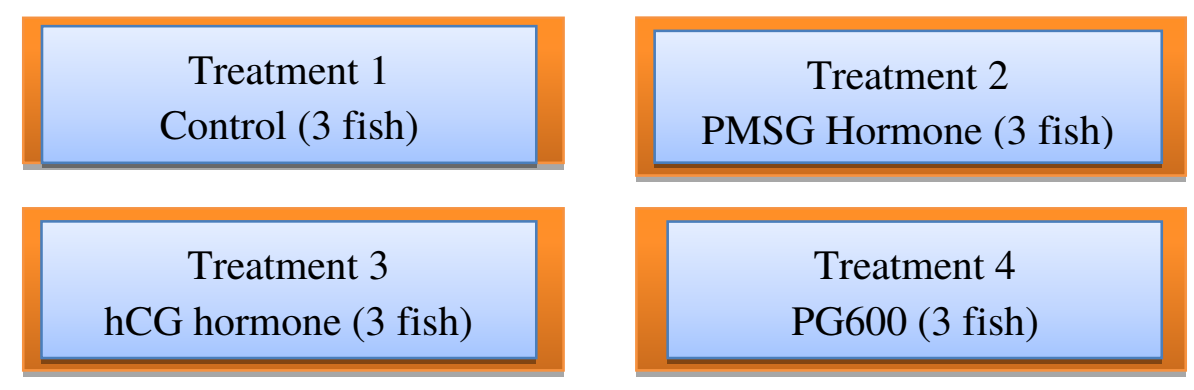

brought in the bloodstream to granulose cells and absorbed into the egg developmental process until reaching a maximum diameter (maturation), then continued with ovulation and spawning process (Nagahama, 2011).

Studies about the gonad maturation of silver pompano using PMSG, hCG, and PG600 hormone are still rarely performed, especially in Indonesia. The latest study has performed hCG anf PMSG hormone induction in silver pompano (Putra\& Razai, 2017) to reach a gonad maturation rate of TKG III for four weeks (four times injection) and spawning process (Putra et al., 2018a; Putra et al., 2018b). Studies about fish maturation induction using PMSG and hCG have many been performed in swamp eels (Putra, 2013; Putra, 2017), tor soro (Farastuti, 2014; Rahimi et al., 2019), eel (Handoyo et al., 2012), silver pompano (Gopakumar et al., 2012; Putra et al., 2018b; Saputra et al.,2019b), catfish (Ahmed, 2017), striped catfish (Samara et al., 2019), nile tilapia (Darliansyah et al., 2017), eel tail catfish (Anggraini et al., 2019; Yulianto et al., 2019), and sea bass (Cerda et al., 1997; Saputra et al., 2019a). This study was performed to analyze the gonad maturation rate of silver pompano induced by different gonadotropin hormones and obtain a potential hormone type for gonad maturation inducement in silver pompano.

\section{MATERIALS AND METHODS}

This study contained four treatments, namely control with $\mathrm{NaCl} 90 \%$ ( $0.5 \mathrm{ml} / \mathrm{kg}$ body weight), PMSG hormone (20 IU/kg body weight), hCG hormone (20 IU/kg body weight), and PG600 hormone (20 IU/kg body weight). The use of 20 IU doze was an applied hormone doze from the previous study of Putra (2013) about a hormonal maturation induction of swamp eel and silver pompano. All treatments induced three broodstock candidates on each treatment. This study comprised some steps.

$$
\text { PG600 (3 fish) }
$$




\section{Broodstock selection}

Selection process was performed on the broodstock used. The broodstock candidate weight used reached $500 \mathrm{~g} /$ broodstock with 7 months old range. The broodstock candidates used were 12 fish and obtained from Fish Fingerling Center, Pengujan, Bintan, Riau Islands.

\section{Container preparation}

The container used in the study was a floating net cage. The floating net cages used were four units with the size of $3 \times 3 \mathrm{~m}^{2}$ as presented on Figure 1.

\section{Silver pompano rearing}

The rearing step of silver pompano contained some activities, namely feeding and fish condition control. Feeding was performed by giving a commercial pelleted feed (37\% protein) with the feeding rate of $3-5 \%$ from fish weight/day. The feeding period was twice, i.e morning (07.00) and afternoon (17.00).

\section{Hormonal injection}

The injection was performed intramuscularly in dorsal part of the fish. Before injected, fish were anesthetized using a clove oil $(1 \mathrm{ml} / 250 \mathrm{~L})$. The hormonal injection doze was based on fish body weight. The injection was performed in four weeks, namely 0 th week (W0), $1^{\text {st }}$ week (W1), $2^{\text {nd }}$ week (W2), and $3^{\text {rd }}$ week (W3).

\section{Parameter observation}

Parameters observed were body weight, gonadosomatic index (GSI), hepatosomatic index (HSI), gonad maturity level (TKG I-IV), gonad histology, and absolute growth. Data sampling was performed at the initial study period (M0) and $4^{\text {th }}$ week of study period (M4). Fish samples taken on the initial and final study period were three fish in each treatment.

\section{Body weight}

Absolute body weight parameter measurement of silver pompano was performed using a digital scale with $1 \mathrm{~g}$ accuracy. Fish were anesthetized first, then measured and noted the measurement result in a gram unit (g). Measurement was performed at the $0^{\text {th }}$ week (W0), $1^{\text {st }}$ week (W1), $2^{\text {nd }}$ week (W2), $3^{\text {rd }}$ week (W3), and $4^{\text {th }}$ week (M4).

\section{Gonadosomatic index (GSI)}

GSI is the measurement result of gonad weight divided with fish body weight multiplied by 100 in a percentage unit $(\%)$. The GSI measurement was performed on the initial (M0) and final (M4) study period. Silver pompano fish were measured their body weight before dissected, then dissection was performed to take the gonad, which was measured using a digital scale (0.01 g accuracy). GSI calculation formula based on (Bromage et al., 2001):

$$
\mathrm{GSI}=\frac{\mathrm{Wg}}{\mathrm{W}} \times 100
$$

Note:

GSI : Gonadosomatic index (\%)

Wg : Silver pompano gonad weight $(\mathrm{g})$

$\mathrm{W} \quad$ : Silver pompano body weight $(\mathrm{g})$

\section{Hepatosomatic index (HSI)}

Hepatosomatic index (HSI) is the calculation result of liver weight divided with body weight multiplied by 100 in a percentage unit (\%). The procedure was performed by measuring the body weight $(\mathrm{W})$, dissection, and measuring the liver weight (Wh). HSI calculation was performed on the initial (M0) and final (M4) study period. HSI calculation used the following formula (Cek et al., 2001):

$$
\mathrm{HSI}=\frac{\mathrm{Wh}}{\mathrm{W}} \times 100
$$

Note:

HSI : Hepatosomatic index (\%)

Wh : Fish liver weight $(\mathrm{g})$

W : Fish body weight (g)

\section{Gonad maturity level (TKG)}

The gonad maturity level can be measured through either a visual or microscopical observation (histology). This study used a visual observation based on the egg nucleus movement and gonad maturity level standard on the following Table 1.

\section{Gonad histology}

Gonad histological observation was performed to identify the microscopical gonad maturation level. The gonad development observation through a histological figure was performed on the initial and final study period. Gonad samples were measured using an analytical scale with $0.01 \mathrm{~g}$ accuracy and preserved using formalin $10 \%$. The histological preparation was performed by sending the gonad samples to the laboratory of pathology, Faculty of Animal Medicines, IPB University. A prepared histological sample 


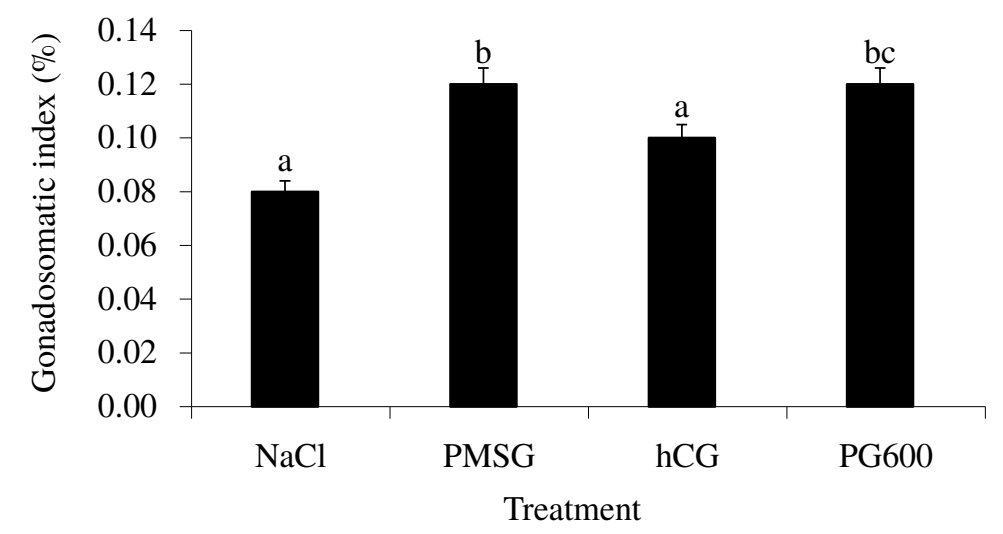

Figure 2. Gonadosomatic index of silver pompano on the final study period. Different letters in graphic indicate a significant difference $(\mathrm{P}<0.01)$.

Table 1. General gonad maturity level (Yaron \& Levavi, 2011); Han et al., 2003)

\begin{tabular}{|c|c|c|}
\hline TKG & Visual & Microscopical \\
\hline $\begin{array}{c}\text { I } \\
\text { Immature }\end{array}$ & $\begin{array}{l}\text { Small ovary and testis is } 1 / 3 \text { of body cavity, oval } \\
\text { egg shape. Pink colored ovary and transparent } \\
\text { white colored testis. }\end{array}$ & $\begin{array}{l}\text { Small egg with low invisibility, } 1-16 \mu \mathrm{m} \\
\text { diameter, transparent. }\end{array}$ \\
\hline $\begin{array}{c}\text { II } \\
\text { Mature }\end{array}$ & $\begin{array}{l}\text { Small ovary and testis covers } 1 / 2 \text { of body cavity, } \\
\text { expanded. Transparent pink colored ovary and } \\
\text { quite symmetrical white colored testis. }\end{array}$ & $\begin{array}{l}\text { Egg is invisible with naked-eyes, clear egg } \\
\text { with } 10-21 \mu \mathrm{m} \text { diameter. }\end{array}$ \\
\hline $\begin{array}{c}\text { III } \\
\text { Mature-to-Ripe }\end{array}$ & $\begin{array}{l}\text { Small ovary and testis is } 1 / 2-2 / 3 \text { of body cavity, } \\
\text { asymmetrical gonad. Yellow colored ovary, } \\
\text { granule and blood stream existence in the } \\
\text { surface, white colored testis. }\end{array}$ & $\begin{array}{l}\text { Egg occurs to be opaque and intransparent } \\
\text { with } 29-52 \mu \mathrm{m} \text { diameter. }\end{array}$ \\
\hline $\begin{array}{l}\text { IV } \\
\text { Ripe }\end{array}$ & $\begin{array}{l}\text { Ovary and testis fill } 2 / 3 \text { until fully in the body } \\
\text { cavity, orange-pink color, bloodstream in the } \\
\text { surface, soft and grey colored testis }\end{array}$ & $\begin{array}{l}\text { Semi-transparent riped egg with } 45-70 \\
\mu \text { m diameter. }\end{array}$ \\
\hline $\begin{array}{c}\mathrm{V} \\
\text { Spent }\end{array}$ & $\begin{array}{l}\text { Ovary and testis fill } 2 / 3 \text { until fully in the body } \\
\text { cavity, orange-pink color, bloodstream in the } \\
\text { surface, soft and grey colored testis }\end{array}$ & $\begin{array}{l}\text { Semi-transparent riped egg with } 51-93 \\
\mu \mathrm{m} \text { diameter. }\end{array}$ \\
\hline
\end{tabular}

was then observed under a microscope with 100 times magnification. The observation result was analyzed descriptively.

The histological preparation procedure was begun as the preserved gonad samples were dried and separated. Gonad samples was cut transversely and soaked into an alcohol 70\%. The first procedure of histological sample preparation (Saeed et al., 2010) was a prepared organ cutting, which was then moved into a cassette and coded based on the treatments. Cassette was moved into a tissue-processor machine in one night for a dehydration process. The embedding process was performed with a paraffin block on a tissue-tek machine forfourhours. Afterfourhours, sample was cut with a microtom at $5 \mu \mathrm{m}$ thick, and the cutting result was enclosed into an object glass, then moved into a waterbath for 15 minutes. The glass sample was pulled and air dried, then moved into an incubator for two hours. The final procedure was a haematoxylin-eosisn (HE) staining, which was then closed with a cover glass.

\section{Data analysis}

The study data were analyzed statistically using an anova with the parameters contained gonadosomatic index, hepatosomatic index, and absolute growth, while a descriptive analysis was performed on the gonad maturity level and gonad histology. When the results showed a significant difference $(\mathrm{P}<0.01)$, then performed a continuous Tukey test.

\section{RESULT AND DISCUSSION}

\section{Gonadosomatic index}

The measurement result of gonadosomatic index indicated that the hormone treatments to fish had a significant effect against the gonad 


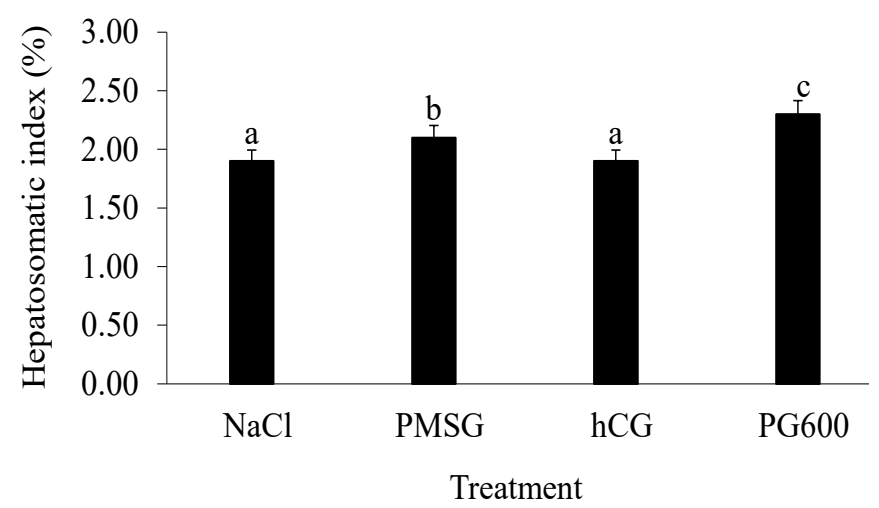

Figure 3. The hepatosomatic index of silver pompano on the final study period in each treatment. Different letters in the graphic indicate a significant difference $(\mathrm{P}<0.01)$.

development. The GSI value is a quantitative value, which draws an alteration during the gonad development and will reach a maximum value when the spawning begins (Putra, 2017; Cek et al., 2001). Increased GSI indicated vitellogenesis and gonad development occurrence during the study period (Magalhães et al., 2012). The vitellogenesis activity caused increased HSI and GSI of fish (Cerda et al., 1997). The GSI values of silver pompano on control, PMSG, hCG, and PG600 treatment were $0.08 \pm 0.03 \% ; 0.12 \pm$ $0.04 \% ; 0.09 \pm 0.09 \%$; and $0.12 \pm 0.06 \%$ of body weight (Figure 2). The best GSI value in this study was found on PG600 treatment. The result of 0.12 $\pm 0.06 \%$ meant that the gonad development of 500 $\mathrm{g}$ silver pompano was $0.12 \%$ of its body weight. The gonadosomatic index result on PG600 hormone treatment was insignificantly different from PMSG hormone treatment $(\mathrm{P}<0.01)$. Based on the ANOVA analysis, the hormone induction treatments which had a significant effect against the gonadosomatic index of silver pompano were found on PMSG and PG600 treatment.

The improved gonad development along with vitellogenesis were suspectively influenced by FSH and LH level (Rafiuddin, 2014), which contained in PMSG and hCG hormone. The combination of PMSG and hCG as the main component of PG600 hormone caused excessive FSH and LH hormone to induce a vitellogenin production. In sockeye salmon, the salmon GnRH (sGnRH) is distributed from olfactory nerves through hypothalamus along with the gonadotropins (GTH) and growth hormones (GH) release (Kim et al., 2011; Heyrati et al., 2010). PMSG hormone contains more follicle stimulating hormone (FSH) and less luteinizing hormone (LH) (Rafiuddin, 2014), thus can induce a gonad maturity process well.
A hormone that influences the vitellogenesis process is FSH or gonadotropin I (Yaron\& Levavi, 2011; Voronina \& Wessel, 2003; Wu et al., 2012). The GSI value in this study was lower than Putra\&Razai(2017) with $0.6 \%$ after induced with PMSG hormone on silver pompano. This was suspected due to a different fish body weight used which reached $1 \mathrm{~kg}$ size, therefore the gonad weight influenced the GSI calculation. A study about the induction of PMSG hormone on swamp eel could improve the GSI value until $0.3 \%$ of body weight after four week rearing and four time injections (Putra, 2017). Furthermore, the utilization of PG600 hormone on swamp eel could improve the GSI value until $0.74 \%$ of body weight (Putra, 2013). The improved GSI value was suspectively influenced by the fish weight. Improved GSI value is also followed with an improved HSI value. The utilization of hCG and PMSG hormone could produce lower GSI values than PG600 hormone utilization. This was suspected due to low FSH level, which induced the gonad development, causing a low GSI value. The utilization of hCG and PMSG hormone that still had lower GSI values than PG600 hormone was considered as a less FSH level in the hormones, which induced the gonad development, causing low GSI value obtained (Putra, 2017; Zadmajid et al., 2018).

\section{Hepatosomatic index}

The hepatosomatic index of silver pompano given the hormone treatments can be seen on Figure 3. The hepatosomatic index (HSI) is a quantitative value which draws the increased liver weight along with gonad development and increased GSI (Cek et al., 2001; Kim et al., 2011). The study result showed that HSI value on each treatment, namely control, PMSG, hCG, and 


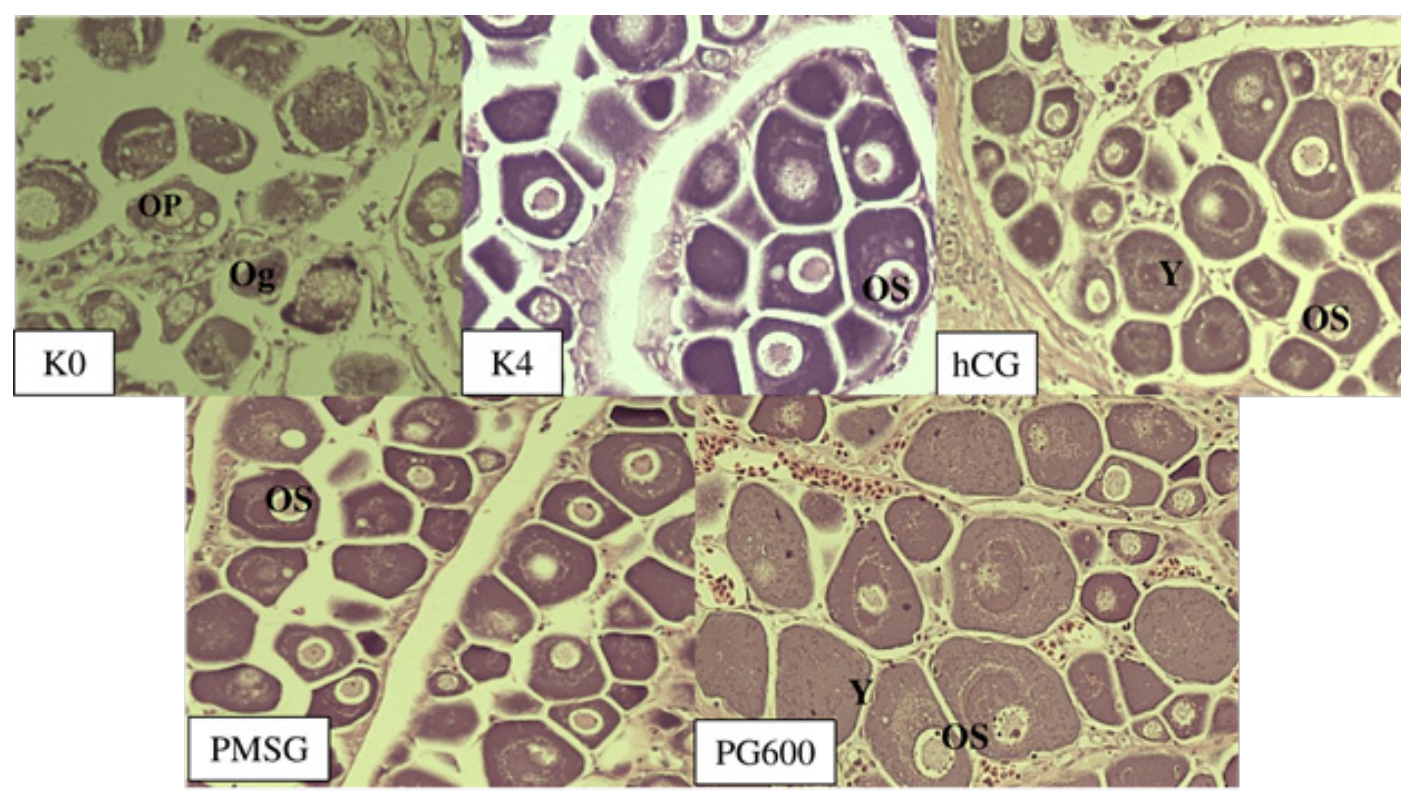

Figure 4. Gonad histology of silver pompano in each treatment on the final study period. Note: K0 (control on the initial period); K4 (control on the $4^{\text {th }}$ week period); Y (egg yolk); OS (secondary oocyte); OP (primary oocyte); Oog (oogonium) (Esmaeili et al., 2017; Behera, 2012; Duarte et al., 2017). 100 times magnification.

PG600, was $1.90 \pm 0.32 \%, 2.08 \pm 0.40 \%, 1.91$ $\pm 0.32 \%$, and $2.30 \pm 0.15 \%$ respectively. Based on the ANOVA analysis, the hormonal induction treatment gave a significant influence against the hepatosomatic index of silver pompano $(\mathrm{P}<0.01)$. Liver did not only develop the weight during the gonad maturation process, but also occurring a darker red whenever approaching the final maturation level (TKG IV). The best result was obtained from PG600 treatment with 2.30\%, which indicated that there was an increased liver weight as the gonad maturation process occurred. PMSG hormone contained more follicle stimulating hormone (FSH) and less luteinizing hormone (LH) (Putra, 2017). The activity of hCG hormone is more similar to LH and less similar to FSH. hCG hormone induced the gonadotropin concentration during the vitellogenesis process and final maturation (Mehdi \& Ehsan, 2011). PG600 hormone was a combination of PMSG and hCG, therefore having more composition and concentration of FSH and $\mathrm{LH}$, which worked more than PMSG and hCG, affecting a faster gonad development, as well as higher GSI and HSI value.

The increased concentration of FSH (GTH-I) induced the aromatase enzyme which converted testosterone into 17 $\beta$-estradiol (Isriansyah, 2011), therefore the vitellogenin synthesis in liver could be conducted (Mylonas et al., 2010; Francis et al., 2011). The gonad maturation is closely related to vitellogenesis process. This was based on the statement of Cek et al. (2001) that liver has a role in synthesizing some materials supplied into the ovarium during the reproductive period. The ratio of liver and body weight on gonad matured fish increases during the vitellogenesis process and decreases during the ovulation process.

\section{Gonad maturity level}

The gonad maturity level of silver pompano on the final study period is presented in the following Table 2.

Table 2. Gonad maturity level of silver pompano on the final study period

\begin{tabular}{cccc}
\hline \multirow{2}{*}{ Treatment } & \multicolumn{3}{c}{ Fish } \\
\cline { 2 - 4 } & 1 & 2 & 3 \\
\hline Control & I & I & II \\
PMSG & II & III & III \\
hCG & II & III & III-IV \\
PG600 & III & IV & IV \\
\hline
\end{tabular}

Tang and Affandi (2004) stated that the gonad maturity level I was marked from the egg cells majority on the oogonium phase (vitellogenin droplet had no egg nucleus), gonad maturity level II was marked from a perinucleolar stage (PNS) as yolk started to form and had a dotted egg nucleus. Gonad maturity level III was a cortical alveolar stage (CAS) with developed and unmerged egg nucleus, brighter colored yolk, and lipid droplets. 


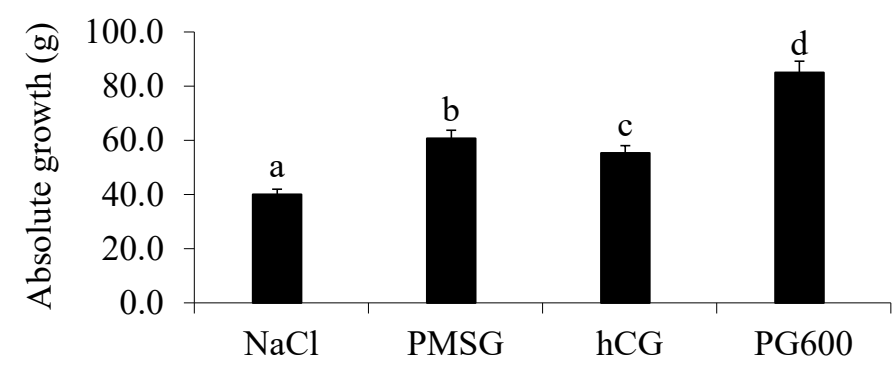

Treatment

Figure 5. The absolute weight growth of silver pompano in each treatment on the final study period. Different letters in the graphic indicate a significant difference $(\mathrm{P}<0.01)$.

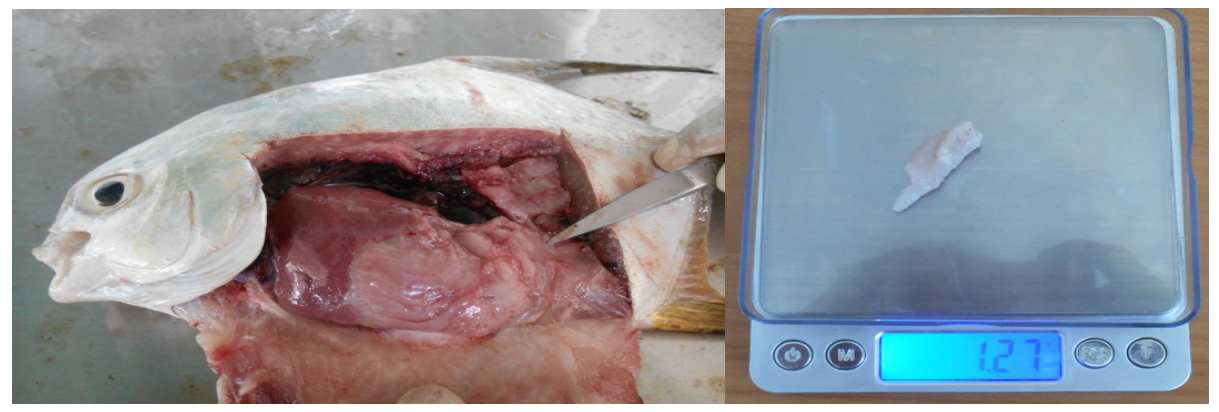

Figure 6. Abdominal contents and gonad of silver pompano (Study documentation, 2017)

Gonad maturity level IV is an oocyte included in the vitelogenic stage (VS), meanwhile oocyte moved into a maturation stage (MS) with the egg nucleus was merged and maximum egg diameter. TKG $\mathrm{V}$ was marked from less number of oocytes after spawning process, while resting range happened as the resting period for preparing the initial phase (Lemos et al., 2011). The anatomical observation result in gonad based on Yaron\&Levavi (2011) was that the application of PG600 hormone cause two of three broodstocks reached TKG IV. These TKG results followed Handrianto et al.(2017), who stated that the induction of PMSG hormone in silver pompano reached a gonad maturity level (TKG) III for four weeks after injected with the doze of $20 \mathrm{IU} / \mathrm{kg}$ body weight. Increased gonad maturation will impact on the improved FSH and LH hormone concentration (Zahri et al., 2018). Increased gonad maturity level with hCG induction also occurred on grey mullet (Cahyono et al., 2019).

\section{Gonad histology}

The gonad histologies of silver pompano on the initial and final study period are presented on Figure 4. Based on Figure 4, the best result was obtained from PG600 treatment as egg nucleus was merged, although there were some egg cells were in the secondary oocyte phase. This proved that PG600 treatment could reach a gonad maturity level III. This result was influenced by some factors, i.e hormone contents, doze, and nutrient levels to support the gonad maturation process. PG600 is composed of PMSG (containing FSH+LH) (Hutagalung et al., 2015) and hCG (FSH+LH) (Nuraini et al., 2008), therefore PG600 was possibly better to induce the fish gonad maturation. Another treatment, such as control, still included in TKG I due to the existence of oogonium that was dominantly found on the egg cells histological figure, while hCG and PMSG treatment showed a gonad development as egg nucleus occurred and moved at the egg corner, but not yet reaching a phase when the egg cell merged as seen on PG600 treatment. The hCG and PMSG treatment were only capable of reaching gonad maturity level (TKG) II. This was possibly influenced by the dozes given, hormone contents, and a possibility that only happened on the seawater fish, i.e moon period (date of $15^{\text {th }}$ until $2^{\text {nd }}$ ) and dark moon period (date of $4^{\text {th }}$ until $\left.14^{\text {th }}\right)$. For moon and dark moon period, studies following this concern has never been proven scientifically, however a broodstock selection is performed on the dark moon period (around date of $15^{\text {th }}$ until $2^{\text {nd }}$ or $3^{\text {rd }}$ on each month) as learned from the experience of fish fingerling center. 


\section{Absolute weight growth}

The weight growth of silver pompano on hormone treatments is presented on Figure 5. The PG600 hormone treatment caused an absolute weight growth of $85 \mathrm{~g}$. This increased weight was suspected due to the influence of feed, gonad development, and lipid deposits (Putra, 2017) which contained in the digestive tract of silver pompano (Hamed et al., 2016; Kumar et al., 2015; Ma et al., 2016; Handrianto et al., 2016; Lemos et al., 2011; Jayakumar et al., 2014; Cavalin \& Weirich, 2009; Belfranin, 2016). Growth is the increased body weight and length as body weight has the supportive components, namely meat, body skeleton (body), skin, body organs, digestive tract, and abdominal lipids. Growth in silver pompano is specifically influenced by the increased lipid weight or also gonad development, although this is less possible as the gonad weight of silver pompano is not much great. The body and abdominal contents of silver pompano are visually seen on the following figure:

Vitellogenesis is the vitellogenin induction and synthesis process in liver by $17 \beta$-estradiol hormone (Rehman et al., 2015), as well as vitellogenin absorption carried by bloodstream into oocytes (Tyler et al., 1991). In vitellogenesis, the environmental factors, such as rain and media temperature, are accepted by the central nervous system and transmitted into the hypothalamus. The GnRH hormone release is a response of hypothalamus against the stimulation of both natural and exogeneous hormones injected into the fish body. Furthermore, Hypophysis synthesizes FSH hormone that works on theca cells on the oocytes, resulting a testosterone production the theca cell layer (Nagahama, 2011). The testosterone hormone is converted into $17 \beta$-estradiol by the aromatase enzyme on the granulose layer. $17 \beta$-estradiol stimulates the liver to synthesize vitelogenin as a yolk candidate (Schaefer et al., 2016).

Vitelogenin is brought by the bloodstream to gonad and absorbed by oocyte follicle layer (Yaron \&Levavi, 2011). The vitelogenin absorption results an enlarged oocyte growth and stops whenever reaching the maximum diameter (Chattopadhyay \& Chattoraj, 2017). In this circumstance, eggs wait for the environmental signal to perform spawning. The gonadosomatic index (GSI) (Fontoura et al., 2018) and hepatosomatic index (HSI) will increase simultaneously along with the vitellogenesis process (Cerda et al., 1997;
Heyrati et al., 2010). The vitellogenin synthesis is influenced by $17 \beta$-estradiol as vitellogenin and andrgens biosynthesis stimulator presented in fish body. This happens as androgens will converted into estrogens by liver aromatase (Elakkanai et al., 2017) and suspected phytoestrogens supplemented in fish feed such as soy beans and alfalfa plant have a positive influence on the fish vitellogenesis (Mehdi et al., 2011; Yaron \& Levavi, 2011). According to Yaron and Levavi (2011), and Ekokotu and Olele (2014), when the vitellogenesis process occurs, the egg yolk granules or globules increase in number and size, resulting an enlarged oocyte volume.

\section{CONCLUSION}

The use of gonadotropin hormones could induce the gonad maturation of silver pompano until gonad maturation level III and IV for four weeks and the best result was obtained from PG600 hormone compared to control and other treatments $(\mathrm{P}<0.01)$.

\section{REFERENCES}

Ahmed MMA, Manofal, Abed EMA. 2017. Induced breeding of Clarias lazera using hormones of HCG and SGnRHa.Scholars Journal of Agriculture and Veterinary Sciences 4: 327-330.

Anggraini W, Putra WKA, Razai TS. 2019. Gonad maturity levels of gray-eel catfish plotosus canius females by injecting human chorionic gonadotropine (hCG). Intek Akuakultur 3: 105-111.

Behera S. 2012. Histological observation of gonads during breeding and non breeding season of Trichogaster fasciatus in Shanti jheel, West Bengal. Journal of Bio Innovation 6: 205-214.

Belfranin CM. 2016. Growth performance of adult Florida pompano Trachinotus carolinus fed semi-purified diets with graded levels of methionine. Thesis. University of Miami.

Bromage N, Porter M, Randall C. 2001. The environmental regulation of maturation in farmed finfish with special reference to the role of photoperiod and melatonin. Aquaculture 197: 63-98.

Cahyono TD, Junior MZ, Carman O. 2019. Stimulasi pematangan gonad ikan belanak Mugil dussumieri menggunakan hormon MT, 
E2, hCG, dan Ovaprim. Jurnal Akuakultur Indonesia 18: 9-22.

Chattopadhyay NR, Chattoraj S. 2017. A review on the reproduction and development in fish. Biomedical Journal of Scientific\& Technical Research 1: 1-5.

Cavalin FG, Weirich CR. 2009. Larval performance of aquacultured Florida pompano Trachinotus carolinus fed rotifers Brachionus plicatilis enriched with selected commercial diets. Aquaculture 292: 67-73.

Cek S, Bromage N, Randall C, Rana K. 2001. Oogenesis, hepatosomatic and gonadosomatic indexes, and sex ratio in rosy barb Puntius conchonius. Turkish Journal of Fisheries and Aquatic Sciences 1: 33-41.

Cerda J, Selman K, Hsiao SM, Wallace RA. 1997. Evidence for the differential regulation of ovarian follicle responsiveness to human chorionic gonadotropin in vitro in a serranid teleost, Centropristis striata. Aquaculture 159: 143-157.

Darliansyah R, Sayyid AE, Rahimi, Hasri I. 2017. The induced of different doses of pregnant mare serumgonadotropin (PMSG) hormone on the gonad maturation of peres fishOsteochilus kappeni. Jurnal Ilmiah Mahasiswa Kelautan dan Perikanan Unsyiah 2: 286-294.

Duarte S, Araújo FG, Sales A, Bazzoli N. 2007. Morphology of gonads, maturity and spawning season of Loricariichthys spixii (Siluriformes, Loricariidae) in a subtropical reservoir. Journal Brazilian Archives of Biology and Technology 50: 1019-1032.

Ekokotu PA, Olele NF. 2014. Cycle of gonad maturation, condition index and spawning of Clarotes laticeps (Claroteidae) In the Lower River Niger. International Journal of Fisheries and Aquatic Studies 1: 144-150

Elakkanai P, Francis T, Ahilan B, Jawahar, P Padmavathy P, Jayakumar N, A. Subburaj. 2015. Role of GnRH, HCG and Kisspeptin on Reproduction of Fishes.Indian Journal of Science and Technology 8: 1-17.

Esmaeili HR, R. Choobineh, H. Zareian, A. Gholamhosseini. 2017. Life history traits and gonad histology of an endemic cyprinid fish, Mond spotted barb, Capoeta mandica from Southern Iran. Caspian Journal of Environmental Science 15: 97-112.

Farastuti ER. 2014. Induction of ovulation and spawning soro Tor soro using combination hormones. Thesis. Institut Pertanian Bogor.
Fontoura NF, Ceni G, Braun AS, Marques CS. 2018. Defining the reproductive period of freshwater fish species using the gonadosomatic index: a proposed protocol applied to ten species of the Patos Lagoon basin. Neotropical Ichthyology 16: e170006

Francis T, Rajagopalsamy CBT, Jeyakumar N, Venkatasamy M, Archanadevi C. 2011. Role of kisspeptin on gonad maturation of striped murrel Channa striatus. Indian Journalof Science $\&$ Technology; $9^{\text {th }}$ ISRPF Issue 4:176177.

Gopakumar G, Abdul Nazar AK, Jayakumar R, Tamilmani G, Kalidas C, Sakthivel M, Rao GS. 2012. Broodstock development through regulation of photoperiod and controlled breeding of silver pompano Trachinotus blochii (Lacepede, 1801) in India. Indian Journal of Fisheries 59: 53-57.

Guzmán JM, Ramos J, Mylonas CC, Mañanós EL. 2011. Comparative effects of human chorionic gonadotropin (hCG) and gonadotropinreleasing hormone agonist $(\mathrm{GnRHa})$ treatments on the stimulation of male Senegalese sole Solea senegalensis reproduction. Aquaculture 316: 121-128.

Hamed SS, Jiddawi NS, Poj B. 2016. Effect of salinity levels on growth, feed utilization, body composition and digestive enzymes activities of juvenile silver pompano Trachinotus blochii. International Journal of Fisheries and Aquatic Studies 4: 279-283.

Han Y, Liao I, Huang Y, He J. 2003. Synchronous changes of morphology and gonad development of silvering Japanese eel Anguilla japonica. Aquaculture 219: 783-796.

Handoyo B, Alimmudin, Utomo NBP. 2012. Growth, feed conversion and retention, and proximate of eel juvenile treated by immersion of recombinant giant grouper growth hormone. Jurnal Akuakultur Indonesia 1: 132-140.

Handrianto R, Razai ST, Putra WKA. 2017. Effect of hormon human chorionic gonadotropin (hCG) and pregnant mare serum gonadotropin (PMSG) on maturation of silver pompanoTrachinotus blochii. Intek Akuakultur 1: 16-22.

Heyrati FP, Amiri BM, Dorafshan S. 2010. Effect of GnRHa injection on milt volume in recentlystripped rainbow trout Oncorhynchus mykiss. Aquaculture Research 41: 487-492

Hutagalung RA, Maheno SW, Faqih AR. 2015. Evaluation of PMSG (Oodev $\left.{ }^{\circledR}\right)$ application 
on hepatosomatic and gonadosomatic index of snakehead fish. Jurnal Akuakultur Indonesia 14: $24-29$

Isriansyah. 2011. Effectiveness of chronically administered HCG and $17 \alpha$-methyltestosterone hormone to $17 \beta$-estradiol concentration and egg development on green catfish Mystus nemurus. Jurnal Riset Akuakultur 6: 263-269.

Jayakumar R, Abdul Nazar AK, Tamilmani G, Sakthivel M, Rameshkumar CKP, Hanumanta Rao G, Gopakumar G. 2014. Evaluation of growth and production performance of hatchery produced silver pompano Trachinotus blochii fingerlings under brackishwater pond farming in India. Indian Journal of Fisheries 61: 58-62.

Kim D, Suzuki Y, Aida K. 2011. The control mechanism of gonadotropin-releasing hormone and dopamine on gonadotropin release from cultured pituitary cells of rainbow trout Oncorhynchus mykiss at different reproductive stages.Fisheries and Aquatic Science 14: 379-388.

Kumar PR, Nazar AKA, Jayakumar R, Tamilmani G, Sakthivel M, Kalidas C, Balamurugan V, Sirajudeen S, Thiaguand G, Gopakumar. 2015. Amyloodinium ocellatum infestation in the broodstock of silver pompano Trachinotus blochii and its therapeutic control. Indian Journal of Fisheries 62: 131-134.

Lemos VM, Junior ASV, Velasco G, Vieira JP. 2011. The reproductive biology of the plata pompano, Trachinotus marginatus (Teleostei: Carangidae), in Southern Brazil. Zoologia 28: 603-609.

Ma Z, Hu J, Liu Y, Yang R, Qin JG, Sun D. 2016. Insulin-like growth factor (IGF) genes in golden pompano Trachinotus ovatus (Linnaeus, 1758) larvae: molecular cloning and response to water temperature and nutrient manipulation. The Israeli Journal of Aquaculture IJA_68.2016.1336: 13

Mehdi Y, Ehsan S. 2011. A review of the control of reproduction and hormonal manipulations in finfish species. African Journal of Agricultural Research 6: 1643-1650.

Magalhães T, Mossolin EC, Mantelatto FL. 2012. Gonadosomatic and hepatosomatic indexes of the freshwater shrimp Macrobrachium olfersii (Decapoda, Palaemonidae) from São Sebastião Island, Southeastern Brazil. PanAmerican Journal of Aquatic Sciences 7: 1-9.
Mylonas CC, Y Magnus, A Gissis, Y Klebano, Y Zohar. 2010. Application of Controlled-release GnRH-deliveried System in Commercial Production of White Bass X Stripped Bass Hybrid (Sunshine bass) Using Captive Broodstocks. Aquaculture 40: 265-280.

Nagahama Y. 2011. Endocrine regulation of gametogenesis in fish. International Journal of Developmental Biology 38: 217-229.

Nuraini N, Safrudin, Nuraini. 2008. Pengaruh kombinasi penyuntikan kelenjar hipofisa ikan mas dan hormon human chorionic gonadotropin terhadap ovulasi dan daya tetas ikan selais. Jurnal Penelitian Teroka Riau IX: 77-85

Putra WKA. 2013. Induction hormone human chorionic gonadotropin andantidopamine of maturation rice field eel Monopterus albus. Jurnal Riset Akuakultur 8: 209-220.

Putra WKA. 2017. Performa maturasi belut sawah Monopterus albus yang diinduksi hormon gonadotropin berbeda performa maturasi belut sawah Monopterus albus yang diinduksi hormon gonadotropin berbeda. Intek Akuakultur 1: 77-86.

Putra WKA, Razai TS. 2017. Effect of pure and combine hormone of pregnant mare serum (PMSG) on Gonadosmatic index, hepatosomatic index of silver pompano fish Trachinotus blochii. Journal of Aquaculture Science 2: 61-71.

Putra WKA, Razai TS, Zulfikar RT, Handrianto R, Zulpikar, Fauzanadi. 2018a. Spawning fish silver pompano Trachinotus blochii study with hormonal induction. Intek Akuakultur 2: 5462.

Putra WKA, Handrianto R, Razai TS. 2018b. Maturation quality of silver pompano fish Trachinotus blochiigonad by human chorionic gonadotropin (hCG) and pregnant mare serum gonadotropin (PMSG) hormone. Jurnal Perikanan Universitas Gadjah Mada 19: 7578.

Rafiuddin MA. 2014. Cloning, characterization and manipulationexpressionof follicle stimulating hormonegene $\beta$ subunit from striped catfish Pangasianodon hypopthalmus for gonad maturation. Thesis. Institut Pertanian Bogor

Rahimi SAE, Nawan A, Hasri I, Putra DF, Ichsan R. 2019. Effect of PMSG+AD hormone variation on the gonad maturation of Pedih 
fish Tor douronensis. IOP Conf. Series: Earth and Environmental Science 348: 1-6.

Rehman MH, Ashraf M, Abbas F, Qureshi IA, Hassan MM, Iqbal KJ, Abbas S. 2015. Effect of different doses of ovaprim (SGnRHa+domperidone) on the egg fecundity and reproductive hormone levels in Channa marulius. The Journal of Animal \& Plant Sciences 25: 1585-1590.

Saeed SS, Reza IM, Bagher AF, Saeed G. 2010. Histological Study of ovarian development and sexual maturity of kutum Rutilus frisii kutum (Kamenskii, 1901). World Applied Sciences Journal 8: 1343-1350.

Samara SH, Fibriana C, Lestari UN, Sudrajat AO. 2019. Performance of pregnant mare serum gonadotropine and vitamin mix in inducting striped catfish Pangasianodon hypopthalamus Rematuration. Jurnal Ilmu Perikanan dan Sumberdaya Perairan 7: 715-723.

Saputra S, Putra WKA, Irawan H. 2019a. The level of gonad maturity of the prospective parent of Lates calcalifer with the induction of Oodev hormone (oocyte devlopment). Intek Akuakultur 3: 12-27.

Saputra R, Putra WKA, Wulandari R. 2019b. Tingkat kematangan gonad ikan bawal bintang Tranchinotus blochii dengan pemberian dosis hormon human chorionic gonadotropine (hCG) yang berbeda. Intek Akuakultur 3: 34-52

Schaefer FJ, Hermelink B, Husmann P, Meeus W, Adriaen J, Wuertz S. 2016. Induction of gonad maturation at different temperatures in burbot Lota lota. Journal of Fish Biology 89: 1-14.
Tang UM, Affandi R. 2004. Biologi Reproduksi Ikan. Pusat Penelitian Kawasan Pantai dan Perairan Universitas Riau, Pekanbaru.

Tyler CR, Sumpter JP, Cambell PM. 1991. Uptake of vitellogenesis into oocyte during early vitellogenic in the rainbouw trout, Oncorincus mykiss. Journal of Fish Biology 38: 681- 689.

Voronina E, Wessel GM. 2003. The Regulation of oocyte maturation. Current Topics in Developmental Biology 58: 53-110.

Wu Y, He Z, Zhang L, Jiang H, Zhang W. 2012. Ontogeny of immunoreactive LH and FSH cells in relation to early ovarian differentiation and development in protogynous hermaphroditic ricefield eel. Biology of Reproduction 86: 1-9.

Yaron Z, Levavi SB. 2011. Endocrine Regulation of Fish Reproduction. In: Farrell A.P (ed.), Encyclopedia of Fish Physiology: From Genome to Environment, volume 2, pp. 15001508. San Diego: Academic Press.

Yulianto T, Putra WKA, Miranti S, Hardiyanti T, Fitriana S, Fauzanadi. 2019. Gonad maturity rate of gray eeltailed catfish with different hCGinduction. Jurnal Perikanan dan Kelautan 9: 95-109

Zadmajid V, Bashiri S, Sharafi N, Butts IAE. 2018.Effect of hCG and Ovaprim ${ }^{\mathrm{TM}}$ on reproductive characteristics of male Levantine scraper, Capoeta damascina (Valenciennes, 1842). Theriogenology 115: 45-56.

Zahri A, Sudrajat AO, Zairin Jr M. 2018. Profil hormon FSH, LH dan estradiol serta kadar glukosa darah sidat, Anguilla bicolor bicolor (Mc Clelland, 1844) yang dirangsang hormon HCG, MT, E2 dan anti dopamin. Jurnal Iktiologi Indonesia 18: 57-67. 